\title{
DECOLONISING THE UNIVERSITY CURRICULUM
}

\author{
L. le Grange \\ Faculty of Education \\ Stellenbosch University \\ Stellenbosch, South Africa \\ e-mail: Ilg@sun.ac.za
}

\section{ABSTRACT}

The student protests of 2015 precipitated a renewed interest in the decolonisation of the university in South Africa, and by association the decolonisation of the university curriculum. The decolonisation of the curriculum is an important conversation, and long overdue, given that the Western model of academic organisation on which the South African university is based, remains largely unchallenged. In this article I add to the conversation by discussing what decolonisation entails, why the need for decolonisation, the importance of rethinking how curriculum is conceived, and outlining some possible ways of decolonising the university curriculum. The purpose is not to provide a set of answers but to open up ways of (re)thinking the university curriculum.

Keywords: decolonisation; university curriculum; higher education transformation; student protests

\section{INTRODUCTION}

The impetus for a renewed interest in decolonising the university curriculum in South Africa is the student protests of 2015. Chetty and Knaus (2016) argue that the student protests are a manifestation of a class struggle in South African universities - research shows that the higher education system is racial and class-based. The effect is that only 15 per cent of the 60 per cent of black students who survive first year eventually complete their studies. They aver that the students who are unsuccessful come from an oppressive, ineffective public school system - that the schools are located in poor communities. In South Africa's wealthiest province, Gauteng, for example, 64 per cent of schools are no-fee paying schools (Mtshali 2015). Poor students are burdened in multiple ways: they are academically underprepared, financially hampered and for some the culture of the university is foreign.

Katlego Dismelo (2015), a PhD candidate at the University of Witwatersrand supports the class struggle argument, but suggests that \#FeesMustFall is not a single issue protest. She writes: 
It is, firstly about access to equal and quality education. It is about teasing out the ever-soconfusing intricacies of class relations in post-apartheid South Africa. It is about eradicating the painful exclusion and daily micro aggressions which go-hand-in-hand with institutional racism within these spaces. And it is also about laying bare the failures of the heterosexual, patriarchal, neoliberal capitalist values which have become so characteristic of the country's universities

Dismelo (2015) goes on to argue that these may seem to be disparate ideological positions, but they are not. They all speak to conditions of structural disenfranchisement experienced by black, poor and outsourced workers in universities. She points out the \#FeesMustFall and its antecedents have all been galvanised by the need for access to those opportunities that improve their lives and that of their loved ones.

At beginning of 2016, Pontsho Pilane argued that protests continued at some universities for three reasons: fees did not fall, they were frozen; outsourcing had not ended; and that academia needs to be decolonised. Concerning the latter, she points out that all recent studentled movements are dedicated to transforming academia into a more inclusive space; quoting EFF Wits leader Vuyani Pambo who said, 'We don't want to treat the symptoms, we want to decolonise the university - that is at the heart of the cause'.

The South African government's responses to \#FeesMustFall protests was to freeze fee increases for 2016, appoint a commission to investigate the feasibility of free higher education and to investigate ways of funding the 'missing middle'. ${ }^{1}$ Concerning the decolonisation of the university, in his speech at the Higher Education Summit held in October 2015 the Minister of Higher Education and Training, Blade Nzimande called for the Africanisation of universities. He stated, 'universities, all of them, must shed all the problematic features of their apartheid and colonial past'. At the summit Nzimande asked universities to look into the issue of decolonising the curriculum. In the Western Cape province, for example, we have seen responses to the call for the decolonisation of the university curriculum: the appointment of a central curriculum committee to coordinate decolonising of the curriculum at the University of Cape Town, an all-day colloquium on the topic at the University of the Western Cape in May this year; and in the same month, a panel presentation and discussion on the topic arranged by the Cape Higher Education Consortium (CHEC) at the Going Global conference held at the Cape Town International Convention Centre (CTICC).

It is against this background that I explore some issues related to the decolonisation of the university curriculum. Specifically, I shall firstly discuss what is meant by decolonisation and why the need to decolonise; secondly, I shall discuss what is meant by curriculum and suggest alternative ways of viewing curriculum; thirdly, I shall discuss the decolonisation of the 
curriculum; finally, I offer some parting thoughts.

\section{WHY DECOLONISATION?}

Before discussing why decolonisation, I shall discuss what decolonisation might entail. Drawing on the work of Poka Laenui, Chilisa (2012) suggests five phases in the process of decolonisation: rediscovery and recovery; mourning; dreaming; commitment and action. Rediscovery and recovery is the process whereby colonised peoples rediscover and recover their own history, culture, language and identity. Mourning refers to the process of lamenting the continued assault on the world's colonised/oppressed peoples' identities and social realities. It is an important part of healing and leads to dreaming. Dreaming is when colonised peoples invoke their histories, worldviews, and indigenous knowledge systems to theorise and imagine alternative possibilities - in this instance a different curriculum. Commitment is when academics/students become political activists who demonstrate the commitment to include the voices of the colonised, in this case, in the university curriculum. Action is the phase where dreams and commitments translate into strategies for social transformation. In other words, the transformation of the university curriculum is both a microcosm of and impetus for broader societal transformation. Smith (1999) identified the following elements of decolonisation: deconstruction and reconstruction; self-determination and social justice; ethics, language, internationalisation of indigenous experiences, history and critique. Deconstruction and reconstruction concerns discarding what has been wrongly written, and interrogating distortions of people's life experiences, negative labelling, deficit theorizing, genetically deficient or culturally deficient models that pathologized the colonised ... and retelling the stories of the past and envisioning the future' (Chilisa 2012, 17). Self-determination and social justice relates to the struggle by those who have been marginalised by the Western academy and about seeking legitimacy for knowledge that is embedded in their own histories, experiences and ways of viewing reality. Ethics relates to the formulation, legislation and dissemination of ethical issues related to the protection of indigenous knowledge systems. Language concerns the importance of teaching/learning in indigenous languages as part of the anti-imperialist struggle. Internationalization of indigenous experiences relates to international scholars sharing common experiences, issues and struggles of colonised peoples in global and local spaces. History, in this instance, involves a study of the past to recover the history, culture and languages of colonised people and to use it to inform the present. Critique concerns a critical appraisal of the imperial model of the academy that 'continues to deny the colonised and historically marginalised other space to communicate from their own frames of reference' 
(Chilisa 2012, 19).

In the discussion on what decolonisation entails, some aspects of why the need to decolonise has been covered. So, what I shall discuss here serve to complement the earlier discussion. Decolonisation is a necessary response to first and second generation colonialism, neo-colonialism and the recent (re)ascendency of neoliberalism. Odora-Hoppers and Richards $(2011,7)$ remind us that first generation colonialism was the conquering of the physical spaces and bodies of the colonised, and that second generation colonialism was the colonisation of the mind through disciplines, such as education, science, economics and law. Neo-colonialism was coined by the first President of independent Ghana, Kwame Nkrumah. It relates to the achievement of technical independence by a country, but that is still under the influence of excolonial or newly developed superpowers. Such superpowers could be international monetary bodies, multinational corporations, cartels as well as education and cultural institutions (Ashcroft, Griffiths and Triffin 2000). Nkrumah argued that neo-colonialism is a more insidious form of colonialism because it is more difficult to detect. It also involves new-elites who were trained by colonialists and that take on the roles of colonialists in countries, post-independence. In recent years we have witnessed the (re)ascendency of neoliberalism which has impacted on the university. In fact, the contemporary university has been referred to as the neoliberal university (Peters 2007). Neoliberalism is variously described but Olssen, Codd and O’Neill (2004) aver that neoliberals have three things in common: a commitment to individual liberty and a reduced state; a shift in policy and ideology against government intervention; and a belief that market forces should be allowed to be self-regulating. The upshot of the revival of neoliberal politics is a change in the role of the state from that of provider (of basic needs of citizens) to that of monitor and regulator.

First and second generation colonialism resulted in the denigration and decimation of indigenous knowledges. Santos $(2014,92)$ refers to the decimation of knowledge as 'the murder of knowledge' which he designates epistemicide. He writes:

Unequal exchanges among cultures have always implied the death of the knowledge of the subordinated culture, hence the death of the social groups that possessed it. In most extreme cases, such as that of European expansion, epistemicide was one of the conditions of genocide. The loss of epistemological confidence that currently afflicts modern science has facilitated the identification of the scope and gravity of the epistemicides perpetrated by hegemonic Eurocentric modernity.

It is because of epistemicide that cognitive justice should be sought.

Since inception, all South African universities adopted Western models of academic 
organisation which largely excluded and decimated the knowledges of colonised people. The colonial model of academic organisation of the university, based on Western disciplinary knowledge, was entrenched during apartheid and has not been redressed in post-apartheid in any serious way. The latter, is the outcome of a negotiated settlement and a 'new' state's adoption of neoliberal policies in a rapidly globalising world. Furthermore, although student demographics at South African universities (particularly in historically white universities) changed significantly in post-apartheid South Africa, staff demographics have not changed in accordance. This has ensured the 'preservation' of colonial academic organisation (including curricula) within universities, akin to Nkrumah's neo-colonialism. The preservation of colonial academic organisation was also done under the guise of academic freedom and institutional autonomy. Another form of neo-colonialism that impacts on the university is the influence of superpowers on the South African state and economy, for example, currently South Africans are living in trepidation of a potential downgrade by rating agencies such as Moody's Investors Service, Standard and Poor's and Fitch. The adoption of neoliberal politics in South African has resulted in public universities becoming state-aided universities rather state-funded universities. At Stellenbosch university, for example, the state subsidy comprises less than one third of the institution's consolidated budget. This situation in part explains rising student fees and undesirable practices such as the outsourcing of workers, and provides the context in which student protests and calls for the decolonisation of universities might be understood.

It is imperative to decolonise South African universities and by association the university curriculum, for the reasons advanced above. However, decolonisation is not an event but a process and it is not necessarily easy to achieve. Moreover, we can't simply turn back the clock - we can't begin on a clean slate. Guattari (2001) argues that we cannot create new ways of living by reversing technological advancement and going back to old formulas which were pertinent when the planet was less densely populated and when social relations were much stronger than they are today. New ways of living are to be found in responding to events (associated with integrated world capitalism) as potential carriers of new possibilities. As Pindar and Sutton $(2001,9)$ write:

It isn't a question of exchanging one model or way of life for another, but of responding to the event as the potential bearer of new constellations of Universes of reference. The paradox is this: although these Universes are not pre-established reference points or models, with their discovery one realizes they were always already there, but only a singular event could activate them.

Furthermore, Dei $(2000,113)$ points out, that indigenous knowledge does not reside in 'pristine 
fashion' outside of the influences of other knowledges. He argues that bodies of knowledge continually influence each other, demonstrating the dynamism of all knowledge systems. Rendering a false dichotomy or 'moral evaluation between good [Indigenous] and bad [conventional/Western] knowledges' (Dei 2000, 113) is therefore not useful. However, Dei (2000, 113) importantly points out the need to challenge imperial ideologies and colonial relations of production, which continually characterise and shape academic practices. Moreover, the exclusion of indigenous knowledges from the academy leaves unchallenged space for the (re)colonisation of knowledges and cultures in local environments and contexts (Dei 2000, 113).

As mentioned the decolonisation of the university is not an easy task as my recent visits to both New Zealand and Canada attest. It would be fair to say that New Zealand is moving into what might be called a post-settlement society. Maori tribes are empowered economically to the extent that some tribes would be considered wealthy by any standards. I was excited to hear upon visiting the University of Waikato that the university pays rent to a Maori tribe and was encouraged to hear that Maori education is offered up to doctoral level. Yet, the university is struggling to incorporate one module on Maori studies in all its undergraduate programmes. On a visit to Canada I discovered that at the University of Saskatschewan three different initial teacher education programmes were offered: one for First Nations students; one for Metis students; and one for Canadian students. This arrangement is based on the principle of selfdetermination and social justice that I described as a key element of decolonisation. But, the arrangement could also foster segregation and leave unchallenged what is offered in the mainstream Canadian programme, in particular. There are no simple answers to the decolonisation of the curriculum and therefore the process should be embarked upon thoughtfully but also be open to experimentation from which much could be learned.

As I turn to a discussion on the decolonisation of the curriculum I suggest that it involves a process of change that does not necessary involve destroying Western knowledge but in decentring it or perhaps deterritorialising it (making it something other than what it is). Before discussing the decolonisation of the curriculum I first critically discuss the term curriculum. Decolonising the curriculum has to incorporate rethinking the term curriculum itself (or how it is conventionally understood).

\section{RETHINKING CURRICULUM}

Even though curriculum was first used in the context of higher education it has not received the same critical treatment as it has in relation to school education. The dominant idea of curriculum 
used in universities across the world is based on the factory model of education developed by Frank Taylor (1911). Gough (2011:3) elaborates on the model and its influence on curriculum:

Taylor's emphasis on designing industrial systems to achieve specified products is reproduced in the objectives-driven curriculum models of Franklin Bobbitt $(1918,1928)$ and Ralph Tyler $(1949)$, and more recently manifested in outcomes-based approaches to ... education curriculum .... Bobbitt, Tyler and Biggs represent curriculum as a simple, tightly coupled system in which it is both possible and desirable to closely align what students do in order to learn with intended learning outcomes and how they are assessed.

Alternative ways of viewing curriculum to the current outcomes-based approach used in South African higher education is therefore necessary. I briefly discuss a few alternative ways of viewing curriculum. Four decades ago Madeleine Grumet defined curriculum as the stories that we tell students about their past, present and future (see Grumet 1981). This view of curriculum enables us to ask which stories students are told about their past, present and future and who tells the stories? Another view of curriculum is that of Ted Aoki (1999) who argued that curriculum should not focus only on the planned (curriculum-as-plan) but also on how it is lived (curriculum-as-lived) - how the curriculum is lived by students and teachers. Legitimating the curriculum-as-lived necessitates taking seriously how students are experiencing the current university curriculum and using this as a basis for its decolonisation. Aoki importantly, pointed out that legitimating the curriculum-as-lived does not discard the curriculum-as-plan, but legitimating the former produces a tensioned space in between the two, that is a space of struggle, creativity and transformation. Curriculum scholars have also distinguished between three broad perspectives on curriculum that has not received much attention in relation to universities: the explicit, hidden and null curriculum. The explicit curriculum is what students are provided with such as module frameworks, prescribed readings, assessments guidelines, etc. The hidden curriculum is what students learn about the dominant culture of a university and what values it reproduces. The null curriculum is what universities leave out - what is not taught and learned in a university. The distinctions help us to ask, for example, what the hidden curriculum of Stellenbosch University is or what the null curriculum of the University of Cape Town is.

More than 40 years ago William Pinar first invoked the etymological root of curriculum, the Latin currere, which means 'to run the course'. He did so to refocus curriculum on the significance of individual experience, 'whatever the course content or alignment with society or the economy' (Pinar 2011, xii). Currere, privileges the individual, and Pinar (2011, 2) argues, is a complicated concept, because each of us is different; in our genetic makeup, our 
upbringings, our families, and more broadly our race, gender, class, and so on.

However, recently, a Canadian scholar Jason Wallin has revisited the notion of currere he rethinks the idea with Deleuze and Guattari (1994) and their contention that a concept is not a name attached to something but a way of approaching the world. Deleuze and Guattari's (1994) interest is not in what a concept is but what it does. Wallin draws attention to the paradoxical character of currere's etymology: its active and reactive forces. Firstly, curriculum can be thought of as an active conceptual force. Thinking curriculum as an active conceptual force means that the concept does not have fixity or closeness - that the term does not convey an a priori image of a pedagogical life. It instead relates to the immanent potential of the becoming of a pedagogical life - the multiple coursings of a pedagogical life that exists prior to thought. As Wallin $(2010,2)$ elaborates:

[To] run implies that the conceptual power of currere is intimate to its productive capacity to create flows, offshoots, and multiplicitous movements. For example, the 'running' roots of rhizomatic bulbs and tubers extend to create new interfaces with other organic and nonorganic bodies, extending the experience of what a body can become .... Running flows of volcanic magma create new courses along and through the ostensible stability of the Earth's mantle, articulating the immanent geomorphic potential of territories to deterritorialise .... A musical 'run' creates lines of flight potentially incongruous with the codes that structure it, overflowing, extending, and traversing tonal registers in producing new affects.

The conceptual power of currere implies newness, creation of things unforeseen, experimentation, expanding of difference and movement. This notion of curriculum opens up multiple pathways for the becoming of pedagogical lives and therefore the basis for decolonisation - difference is valued for its intrinsic worth. In its reactive form currere colonises, and one way of knowing becomes the way of knowing. The reactive power of currere severs currere of its immanent potential to become other.

Alternative views of curriculum such as: the stories students are told about their past present and future; curriculum-as-lived, hidden and null curriculum; and the active conceptual force of currere open up possibilities for decolonising the university curriculum. But, a discussion on what is central to the decolonisation of the curriculum as well as how it could be done is necessary; to which I now turn.

\section{DECOLONISING THE CURRICULUM}

There are several approaches that one might take in decolonising the curriculum. But central to any approach must be rethinking of the subject. Le Grange (2015) argues that decolonisation of the curriculum must involve liberating thought from the fetters of cartesian duality - from 
Descartes cogito, 'I think therefore I am'. He argues that Ubuntu (I am because we are) and the active force of currere celebrate the oneness of mind and body and the oneness of humans and the more-than-human-world. Rather than subjectivity being individual, it is ecological. A decolonised curriculum is evidenced by a shift in subjectivity from the arrogant 'I' (of Western individualism) to the humble 'I' - to the 'I' that is embedded, embodied, extended and enacted. In an ever changing world the pathways for becoming of a pedagogical life cannot be known or defined. Ubuntu-currere signifies both our movement in the world and how the world moves through us, which generates potentially creative ways for us to inhabit the world. The oneness of the self and other humans as a microcosm of the oneness of self and the cosmos provides impetus for becomings that are caring towards other humans and the more-than-human world.

The decolonised curriculum is based on the 4Rs central to an emergent Indigenous paradigm. The 4Rs are: relational accountability, respectful representation, reciprocal appropriation, and rights and regulation. Relational accountability concerns the fact that all parts of the curriculum is connected and that the curriculum is accountable to all relations (human and more-than-human). Respectful representation relates to how the curriculum acknowledges and creates space for the voices and knowledges of Indigenous peoples. Reciprocal appropriation relates to ensuring that the benefits of knowledge produced and transmitted are shared by both communities and universities. Rights and regulation refers to observing ethical protocols that accord ownership of knowledge (where appropriate) to Indigenous peoples of the world (see Chilisa 2012).

Decolonisation of the curriculum could involve a range of possibilities. I shall briefly outline a few of these. For more details on some of these, see Le Grange (2014). The first possibility involves the radical rethinking of Western disciplines, which Odora-Hoppers and Richards $(2011,3)$ describe as, 'distant, antiseptic and removed from the experiences of the lived world [that] comes from recognising the pain, anger and anguish being experienced in society'. Such rethinking requires the expansion of empirical beyond mere observation and listening, so as to include knowing through the tastes, pain, and hunger of our bodies and through expressions of anger, passion and desire. This links my earlier discussion on mourning and healing that is integral to the process of decolonisation. The second possibility is through emerging transdisciplinary knowledge, but not based on a socially distributed knowledge system that only comprises those produced by the university but one expanded to include ordinary citizens (including Indigenous communities). A third approach would be to explore ways of developing and designing locally and regionally relevant curricula where Western epistemologies continue to dominate and unequal power relations that remain prevalent. A 
stepping stone for meeting this challenge is to draw on work done in the sociology of science which places emphasis on the performative side of knowledge and that deemphasises the representational side of knowledge (Turnbull 1997; Le Grange 2007). A focus on the performative side of knowledge decentres (not destroys) dominant knowledge systems and produces third spaces (spaces in between) where seemingly disparate knowledges can be equitably compared and function to work together. Empirical verification/falsification ceases to be the golden standard and the new knowledge system is based on the social organisation of trust. A fourth approach, in the African context, is for students to learn together about the origin of human beings, and the epistemologies that emerged from the Cradle of Humankind that Nabudere $(2011,159)$ refers to as Afrikology:

Afrikology seeks to build on the achievements of African people and the rest of humanity in order to emancipate themselves from the dehumanization imposed on them by Western civilization .... We pursue this root from which human knowledge was first produced and then spread to the rest of the world ..., especially Greece and modern Europe, and then return to the cradle in order to sum up human experience. This, as we have seen, has enabled us to re-assert the original knowledge that was fabricated by the Greeks and emulated by Europeans scholars who fabricated and 'methodised' it further to the level of senseless abstraction and fragmentation.

A fifth possibility is to draw inspiration from the approach used by the Intercultural University of the Indigenous Nations and Peoples, Amawtay Wasi, in Ecuador. The curriculum pathway comprises three cycles: cycle in the formation of ancestral sciences (doing community, learning to learn); cycle of Western sciences (learning to un-learn and then re-learn); cycle of interculturality (learning to un-learn and re-learn and going from learning to undertaking) (for a detailed discussion see De Carvalho and Florez-Florez 2014).

\section{SOME PARTING THOUGHTS}

Ongoing student protests (which begun 2015) has given impetus to a renewed interest in the decolonisation of the university curriculum. We witnessed several responses to calls by students for the decolonisation the university, including responses from the Minister of Higher Education and Training and universities. These responses are long overdue because the academic organisation of universities (including curricula) remains largely unchanged and unchallenged in post-apartheid. In a book entitled Violence, the Slovenian philosopher Žižek (2009) relates an old story of a worker suspected of stealing. So every evening when he leaves the factory his wheelbarrow is carefully checked, but the guards find nothing. Eventually, the penny drops: the worker is stealing the wheelbarrows. The point of the story is that we often 
focus on objects of inquiry without seeing the carriers of the objects of inquiry. In Žižek’s case, how language is a carrier of violence and in our discussion how curriculum is a carrier of colonialism. Therefore, in the article I argued that the term curriculum (or its dominant conception) needs to be rethought. I discussed how what decolonisation entails, why the need to decolonise, the importance of rethinking curriculum and outlining possible approaches to decolonising the curriculum. The approaches suggested are not mutually exclusive. I have attempted to add to an ongoing and important conversation, and a lot more can be said on the topic. I have not aimed to provide simple answered to difficult questions but to open ways of (re)thinking the decolonisation of the university curriculum.

\section{NOTE}

1. The 'missing middle' are those students who do not qualify for the National Student Financial Aid Scheme (NSFAS) but also cannot afford to pay university fees.

\section{REFERENCES}

Aoki, T. 1999 Rethinking curriculum and pedagogy. Kappa Delta Pi Record. Summer: 180-181.

Ashcroft, B., G. Griffiths and H. Tiffin. 2000. Post-colonial studies: The key concepts. London: Routledge.

Chetty, R. and C. Knaus. 2016. Why South Africa's universities are in the grip of a class struggle. Sunday Times. http://www.timeslive.co.za/sundaytimes/opinion/2016/01/13/Why-SouthAfrica\%E2\%80\%99s-universities-are-in-the-grip-of-a-class-struggle (accessed 28 April 2016).

Chilisa, B. 2012. Indigenous research methodologies. Los Angeles: Sage publications.

DeCarvalho, J. J. and J. Flórez-Flórez. 2014. The meeting of knowledges: A project for the decolonisation of the university in Latin America. Postcolonial Studies 17(2): 122-139.

Dei, G. 2000. Rethinking the role of indigenous knowledges in the academy. International Journal of Inclusive Education 4(2): 111-132.

Deleuze, G. and F. Guattari. 1994. What is Philosophy? H. Tomlinson and G. Burchell (Trans.). New York: Columbia University Press.

Disemelo, K. 2015. Student protests are about much more than just \#FeesMustFall. Mail\&Guardian. http://mg.co.za/author/katlego-disemelo (accessed 28 April 2016).

Gough, N. 2011. A complexivist view of higher education: Implications for curriculum design and research on teaching and learning. Invited keynote address at the $5^{\text {th }}$ annual university teaching and learning conference. Durban: University of KwaZulu-Natal, 26-28 September.

Grumet, M. R. 1981. Restitution and reconstruction of educational experience: An autobiographical method for curriculum theory. In Rethinking curriculum studies: A radical approach, ed. M. Lawn and L. Barton, 115-130. London: Croom Helm.

Guattari, F. 2001. The three ecologies. Trans. Ian Pindar and Paul Sutton. London: The Athlone Press.

Le Grange, L. 2007. Integrating western and indigenous knowledge systems: The basis for effective science education in South Africa? International Review of Education 53(5-6): 577-591.

Le Grange, L. 2014. Currere's active force and the africanisation of the university curriculum. South African Journal of Higher Education 28(4): 1284-1294.

Le Grange, L. 2015. Currere’s active force and the concept of Ubuntu. Keynote address at the triennial 
conference of the International Association for the Advancement of Curriculum Studies (IAACS). University of Ottawa. 26-30 May.

Mtshali, N. 2015. A little more money for no-fee schools. http://www.iol.co.za/news/southafrica/gauteng/a-little-more-money-for-no-fee-schools-1806803 (accessed 12 May 2016).

Nabudere, D. 2011. Afrikology, philosophy and wholeness: An epistemology. Pretoria: Africa Institute of South Africa.

Nzimande, B. 2015. Speech by Minister Blade Nzimande at the Higher Education Summit held at the Inkosi Albert Luthuli ICC, Durban. http://www.gov.za/speeches/speech-minister-be-nzimandehigher-education-summit-held-inkosi-albert-luthuli-icc-durban (accessed 12 May 2016).

Odora-Hoppers, C. and H. Richards. 2011. Rethinking thinking: Modernity's 'other' and the transformation of the university. Pretoria: Unisa Press.

Olssen, M., J. Codd and A. O’Neill. 2004. Education policy: Globalization, citizenship and democracy. London: Sage publications.

Peters, M. 2007. Knowledge economy, development and the future of higher education. Rottedam/Tapei: Sense publishers.

Pilane, P. 2016. Three reasons why \#FeesMustFall protests will continue. Mail\&Guardian. http://mg.co.za/article/2016-01-13-three-reasons-why-feesmustfall-protests-will-continue (accessed 28 April 2016).

Pinar, W. F. 2011. The character of curriculum studies: Bildung, currere and the recurring question of the subject. New York: Palgrave MacMillan.

Pindar, I. and P. Sutton. 2001. Translators' introduction. In The three ecologies, ed. F. Guattari. Translated by I. Pindar and P. Sutton. London: The Athlone Press.

Smith, L. 1999. Decolonising methodologies: Research and indigenous peoples. London: Zed Books.

Santos, B. 2014. Epistemologies of the south: Justice against epistemicide. Boulder: Paradigm Publishers.

Taylor, F. W. 1911. The principles of scientific management. New York: Harper \& Brothers.

Turnbull, D. 1997. Reframing science and other local knowledge traditions. Futures 29(6): 551-562.

Wallin, J. J. 2010. A Deleuzian approach to curriculum: Essays on a pedagogical life. New York: Palgrave Macmillan.

Žižek, S. 2009. Violence. London: Profile Books. 